\title{
Front Matter: Volume 7172
}

, "Front Matter: Volume 7172," Proc. SPIE 7172, Endoscopic Microscopy IV, 717201 (6 March 2009); doi: 10.1117/12.825133

SPIE. Event: SPIE BiOS, 2009, San Jose, California, United States 


\title{
PROGRESS IN BIOMEDICAL OPTICS AND IMAGING
}

Vol. 10, No. 12

\section{Endoscopic Microscopy IV}

\author{
Guillermo J. Tearney \\ Thomas D. Wang \\ Editors
}

25-26 January 2009

San Jose, California, United States

Sponsored and Published by

SPIE

Volume 7172 
The papers included in this volume were part of the technical conference cited on the cover and title page. Papers were selected and subject to review by the editors and conference program committee. Some conference presentations may not be available for publication. The papers published in these proceedings reflect the work and thoughts of the authors and are published herein as submitted. The publisher is not responsible for the validity of the information or for any outcomes resulting from reliance thereon.

Please use the following format to cite material from this book:

Author(s), "Title of Paper," in Endoscopic Microscopy IV, edited by Guillermo J. Tearney, Thomas D. Wang, Proceedings of SPIE Vol. 7172 (SPIE, Bellingham, WA, 2009) Article CID Number.

ISSN $1605-7422$

ISBN 9780819474186

Published by

SPIE

P.O. Box 10, Bellingham, Washington 98227-0010 USA

Telephone +1 3606763290 (Pacific Time) · Fax +1 3606471445

SPIE.org

Copyright @ 2009, Society of Photo-Optical Instrumentation Engineers.

Copying of material in this book for internal or personal use, or for the internal or personal use of specific clients, beyond the fair use provisions granted by the U.S. Copyright Law is authorized by SPIE subject to payment of copying fees. The Transactional Reporting Service base fee for this volume is $\$ 18.00$ per article (or portion thereof), which should be paid directly to the Copyright Clearance Center (CCC), 222 Rosewood Drive, Danvers, MA 01923. Payment may also be made electronically through CCC Online at copyright.com. Other copying for republication, resale, advertising or promotion, or any form of systematic or multiple reproduction of any material in this book is prohibited except with permission in writing from the publisher. The CCC fee code is 1605$7422 / 09 / \$ 18.00$.

Printed in the United States of America.

Publication of record for individual papers is online in the SPIE Digital Library.

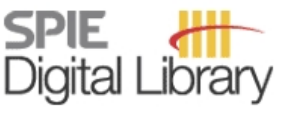

SPIEDigitalLibrary.org

Paper Numbering: Proceedings of SPIE follow an e-First publication model, with papers published first online and then in print and on CD-ROM. Papers are published as they are submitted and meet publication criteria. A unique, consistent, permanent citation identifier (CID) number is assigned to each article at the time of the first publication. Utilization of CIDs allows articles to be fully citable as soon they are published online, and connects the same identifier to all online, print, and electronic versions of the publication. SPIE uses a six-digit CID article numbering system in which:

- The first four digits correspond to the SPIE volume number.

- The last two digits indicate publication order within the volume using a Base 36 numbering system employing both numerals and letters. These two-number sets start with 00, 01, 02, 03, 04 , 05, 06, 07, 08, 09, 0A, OB ... 0Z, followed by 10-1Z, 20-2Z, etc.

The CID number appears on each page of the manuscript. The complete citation is used on the first page, and an abbreviated version on subsequent pages. Numbers in the index correspond to the last two digits of the six-digit CID number. 


\section{Contents}

$\checkmark \quad$ Conference Committee

\section{SESSION 1 MICROMIRROR TECHNIQUES}

717203 A confocal micro-imaging system incorporating a thermally actuated two axis MEMS scanner [7172-02]

S. P. Poland, L. Li, D. Uttamchandani, J. M. Girkin, Univ. of Strathclyde (United Kingdom)

717204 New developments in two photon endoscopy [7172-04]

M. Schwarz, I. Riemann, Fraunhofer Institute of Biomedical Technology (Germany);

M. Weinigel, K. König, JenLab GmbH (Germany); B. Messerschmidt, Grintech GmbH

(Germany); R. Le Harzic, Fraunhofer Institute of Biomedical Technology (Germany)

\section{SESSION 2 NEW TECHNIQUES}

717206 Combined spectrally encoded confocal microscopy and optical frequency domain imaging system [7172-06]

D. Kang, M. J. Suter, C. Boudoux, Wellman Ctr. for Photomedicine, Massachusetts General Hospital (United States); P. S. Yachimski, Massachusetts General Hospital (United States); B. E. Bouma, Wellman Ctr. for Photomedicine, Massachusetts General Hospital (United States); N. S. Nishioka, Massachusetts General Hospital (United States); G. J. Tearney, Wellman Ctr. for Photomedicine, Massachusetts General Hospital (United States)

\section{SESSION $3 \quad$ OCT/OFDI}

7172 OD Design of a handheld optical coherence microscopy endoscope [7172-13]

V. R. Korde, College of Optical Sciences, The Univ. of Arizona (United States; E. Liebmann, The Univ. of Arizona (United States); J. K. Barton, College of Optical Sciences, The Univ. of Arizona (United States) and The Univ. of Arizona (United States)

\section{SESSION 4 CLINICAL SYSTEMS}

7172 0G Deep high-resolution fluorescence microscopy of full organs: the benefit of ultraminiature confocal miniprobes [7172-16]

F. Schwarz, A. Le Nevez, M. Genet, A. Osdoit, F. Lacombe, Mauna Kea Technologies (France)

$7172 \mathrm{OH} \quad$ Clinical results with acridine orange using a novel confocal laparoscope [7172-17]

A. A. Tanbakuchi, College of Optical Sciences, The Univ. of Arizona (United States) and The Univ. of Arizona (United States); A. R. Rouse, K. D. Hatch, The Univ. of Arizona (United States); A. F. Gmitro, College of Optical Sciences, The Univ. of Arizona (United States) and The Univ. of Arizona (United States); 
$71720 \mathrm{~J}$ Affinity fluorescence-labeled peptides for the early detection of cancer in Barrett's esophagus [7172-19]

M. Li, Univ. of Michigan (United States); S. Lu, Xi'an Jiaotong Univ. (China); C. Piraka, H. Appelman, R. Kwon, Univ. of Michigan (United States); R. Soetikno, T. Kaltenbach, VA Palo Alto Health Care System (United States); T. D. Wang, Univ. of Michigan (United States) and VA Palo Alto Health Care System (United States) and VA Ann Arbor Health Care System (United States)

\section{SESSION 5 SPECTROSCOPIC METHODS}

7172 OK Fiber optic FIIR instrument for in vivo detection of colonic neoplasia [7172-20]

M. Van Nortwick, Univ. of Michigan (United States); J. Hargrove, R. Wolters, STI Medical Systems (United States); J. M. Crawford, M. Arroyo, Univ. of Florida College of Medicine (United States); M. Mackanos, C. H. Contag, Stanford Univ. (United States); T. D. Wang, Univ. of Michigan (United States)

\section{POSTER SESSION}

717200 Rotational second harmonic generation endoscopy with $1 \mu \mathrm{m}$ fiber laser system [7172-24] G. Liu, T. Xie, Beckman Laser Institute, Univ. of California, Irvine (United States); L. Yu, J. Su, Univ. of California, Irvine (United States); I. V. Tomov, Q. Wang, B. Rao, J. Zhang, Beckman Laser Institute, Univ. of California, Irvine (United States); Z. Chen, Beckman Laser Institute, Univ. of California, Irvine (United States) and Univ. of California, Irvine (United States)

Author Index 


\section{Conference Committee}

Symposium Chairs

James G. Fujimoto, Massachusetts Institute of Technology (United States)

R. Rox Anderson, Wellman Center for Photomedicine, Massachusetts General Hospital (United States) and Harvard School of Medicine (United States)

Program Track Chairs

Tuan Vo-Dinh, Duke University (United States)

Anita Mahadevan-Jansen, Vanderbilt University (United States)

Conference Chairs

Guillermo J. Tearney, Wellman Center for Photomedicine, Massachusetts General Hospital (United States)

Thomas D. Wang, University of Michigan (United States)

Program Committee

Arthur F. Gmitro, The University of Arizona (United States)

Martin Harris, Optiscan (Australia)

Ralf Kiesslich, Johannes Gutenberg-Universität Mainz (Germany)

Francois Lacombe, Mauna Kea Technologies (France)

Stephen Lam, The BC Cancer Research Center. (Canada)

Hiroshi Mashimo, Harvard Medical School (United States)

Kenzi Murakami, Olympus Corporation (Japan)

Norman S. Nishioka, Massachusetts General Hospital (United States)

Mark J. Schnitzer, Stanford University School of Medicine (United States)

Peter T. C. So, Massachusetts Institute of Technology (United States)

Session Chairs

1 Micromirror Techniques

Thomas D. Wang, University of Michigan (United States)

2 New Techniques

Guillermo J. Tearney, Wellman Center for Photomedicine, Massachusetts

General Hospital (United States)

3 OCT/OFDI

Stephen Lam, The BC Cancer Research Center (Canada) 
Clinical Systems

Arthur F. Gmitro, The University of Arizona (United States)

5 Spectroscopic Methods

Thomas D. Wang, University of Michigan (United States)

Proc. of SPIE Vol. $7172717201-6$

Downloaded From: https://www.spiedigitallibrary.org/conference-proceedings-of-spie on 26 Apr 2023 Terms of Use: https://www.spiedigitallibrary.org/terms-of-use 